\title{
THE REGULATORY SYSTEM OF INTERNATIONAL MIGRATION PROCESSES IN THE CONTEXT OF GLOBALIZATION ${ }^{1}$
}

Petrushenko Y.M., Doctor of Economics, professor

The Department of International Economic Relations, Sumy State University, y.petrushenko@uabs.sumdu.edu.ua

Zemlyak N.V., PhD-student,

The Department of International Economic Relations, Sumy State University, n.zemliak@uabs.sumdu.edu.ua

Petrenko S.V., Student,

The Department of International Economic Relations, Sumy State University, sofialit3@gmail.com

In the context of globalization, all world economies unite, interact and develop in a single system of production. However, the world economy largely depends on the formation and development of the world labor market. Thus, migration is one of the main mechanisms and factors affecting individual countries and the world economy as a whole.

With the intensification of globalization processes, the demand for staff of different levels of qualification in the labor market is met by the supply of workers, regardless of the country in which they live. This phenomenon leads to international labor migration. Despite the fact that the migration of highly qualified personnel leads to intellectual decline and lack of educated population in the country from which workers migrate. Instead, the uncontrolled migration of low-skilled personnel in the host country can lead to a sharp rise in unemployment among the local population, criminal offenses, social discontent of citizens, which will negatively affect the authority of the state in the world. Therefore, the study of the system of regulation of migration processes and the introduction of ways to improve it will help harmonize the socio-economic situation in the world and make migration more profitable and safe for countries and its citizens.

The article reflects the main modern trends in international migration processes: the directions of external labor migration, the scale of the departure of labor migrants to different countries, determined the reasons for such tendencies. In the course of the research, the methods by which these processes are regulated to improve the economies of countries and the safety of labor migrants are considered.

The article also describes the impact of the COVID-19 pandemic on the mobility of Ukrainian citizens and methods of overcoming the consequences of this impact. The activities described in the article related to migration and population mobility will mitigate the long-term impact of the pandemic, help strengthen the protection of Ukrainian citizens abroad, as well as expand the opportunities for their socio-economic integration into local communities.

Keywords: globalization, migration processes, international labor migration, potential migration, state regulation of migration.

DOI: $10.21272 / 1817-9215.2021 .1-29$

\section{INTRODUCTION}

The active intensification of globalization processes is accompanied by an intensive increase in the level of international migration, including for employment. Given this fact, the search for optimal and effective methods of migration management is extremely important to ensure socio-economic benefits from the participation of countries in migration processes, as well as to protect the internal market and attract new highly qualified personnel.

To effectively identify current trends, as well as ways and methods of regulating international migration in the context of globalization, it is advisable to study and evaluate migration flows. Therefore, the analysis of statistical data on the unemployment rate, demographic situation, volumes and directions of external labor migration will provide reliable data on the real situation.

\section{ANALYSIS OF RECENT SOURCES AND PUBLICATIONS}

Important theoretical and practical aspects of migration regulation form the basis of research by domestic and foreign scientists, in particular scientists V.S. Kravtsiv,

\footnotetext{
${ }^{1}$ The article was published as part of a research projects "Convergence of economic and educational transformations in the digital society: modeling the impact on regional and national security"(No. 0121U109553) and "Reforming the lifelong learning system in Ukraine for the prevention of the labor emigration: a coopetition model of institutional partnership" (No. 0120U102001).
} 
U.Ya. Sadova [2], E.M. Libanova [3], O.V. Nagornova [8] and others. However, despite the fact that the works of these scientists reflect important aspects of migration, the peculiarities of labor migration in modern society are still insufficiently studied and appear to be, of course, relevant for empirical sociological research.

\section{RESEARCH RESULTS}

When studying migration processes and mechanisms of their regulation, first of all it is necessary to define the concept of migration. The term "migration" comes from Latin and means "resettlement". Referring to the reference literature, it is defined as "the movement of the population within one country or from one country to another" [1]. Also in many sources there is another definition of migration: "Migration is the process of moving people across the borders of certain territories with a change of residence forever or for a long time" [2, P. 5].

The number of international migrants around the world continues to grow rapidly over the past few years. According to the data provided by various state institutions, the volume of migration for employment is from 1.5 to 5 million people. However, the most reliable figure is 3 million people - the number of Ukrainian citizens working abroad at the same time, calculated according to the number of people who pay taxes in Ukraine, the volume of unregistered employment and possible errors [3, P. 14].

The purpose of migration is a necessity to find a job, a new sphere of work, or lack of employment opportunities at the previous place of residence, or insufficient labor efficiency in their home country. There are sharp differences between countries in the levels of unemployment, wages, the cost of living in many other indicators of living standards, which are a factor in the constant supply of international migration [4, P. 176].

A characteristic feature of modern migration is that its flows consist of two directions, and, therefore, the state itself can be both a donor country and a recipient country. One of the largest centers of international labor migration is Western Europe, in particular the EU countries. The main donor countries for some European countries are: Algeria, Morocco and Portugal for France; Italy and Morocco for Belgium; Turkey, Yugoslavia, Italy, Greece, Ukraine and Poland for Germany; Turkey, Ukraine and Morocco for the Netherlands; Italy, Spain for Switzerland; India for Great Britain [5]. Thus, we can single out the main countries to which the population of Ukraine migrates for the sake of earning: Poland, Germany, Italy, the Czech Republic and the Russian Federation can also be added to this list.

It should be noted that access to statistics on the scale of emigration of Ukrainians in individual countries is limited, since retrospective data were either not collected or could not be compared using different calculation methods. Accordingly, when analyzing the scale of the departure of labor migrants to the EU countries, the indicator of the number of residence permits issued to Ukrainians in the EU countries, published by Eurostat, is used (Table 1) [6,7].

The scale of migration is so significant that it really affects the demographic situation of the countries. At first, the economically favorable mass use of foreign labor force causes a number of acute demographic and socio-economic problems for the developed EU countries. Therefore, governments apply effective methods to regulate the migration of the population to prevent the occurrence of irreversible processes in the economic sphere.

With the intensification of globalization, migration is also regulated through market relations. This is done by forming supply and demand for labor of different qualifications and with different levels of pay. It should be noted that in the first place are the interests of the employer, who seeks to save on social security contributions and taxes.

As the labor market is not able to independently control the scale of movement of migrant workers, especially low-skilled workers, there is a need for government regulation. Executive bodies are responsible for the interstate distribution of employees. But also specially created international organizations, such as UNESCO, the International Organization for Migration and the International Labor Organization, study and regulate some aspects of migration processes in the world. State regulation of external labor migration should be defined as a component of state regulation of the economy, its socio-economic orientation, in the context of demography and employment, taking into account the impact of legal regulation and basic 
and specific functions of public administration [8, P. 8]. Processes takes the form of regulating the quantitative and qualitative composition of migrants, protecting their rights and freedoms. An important element of state migration policy is to establish the legal status of migrant workers, which determines their socio-economic, labor and other rights enshrined in international treaties and national legislation $[9$, P. 42].

Table 1 - The emigration dynamics of the population of Ukraine to the EU and the Russian

\begin{tabular}{|c|c|c|c|c|c|c|}
\hline \multirow{2}{*}{ Country } & 2013 & 2014 & 2015 & 2016 & 2017 & 2018 \\
\hline Poland & 75168 & 104730 & 171769 & 250054 & 430081 & 512552 \\
\hline Russia & 43586 & 49411 & 55037 & 126819 & 194180 & 178274 \\
\hline Czech Rep. & 5392 & 4714 & 7453 & 3392 & 3365 & 7712 \\
\hline Italy & 5521 & 18152 & 18622 & 12867 & 23207 & 24223 \\
\hline Germany & 15409 & 8493 & 13996 & 8761 & 7850 & 6867 \\
\hline Portugal & 4413 & 3687 & 3637 & 3595 & 3809 & 3893 \\
\hline Spain & 3179 & 4548 & 4838 & 6163 & 5667 & 6500 \\
\hline Slovakia & 409 & 773 & 873 & 2053 & 1908 & 2828 \\
\hline Hungary & 297 & 398 & 476 & 598 & 1488 & 1086 \\
\hline
\end{tabular}

Ukraine's migration policy is developing in parallel with the development of international cooperation in this area. In 1996, Ukraine received observer status with the International Organization for Migration (IOM) and opened a representative office, in 2001 Ukraine applied for membership in IOM, and in 2002 the Parliament of Ukraine ratified the organization's charter. The IOM Office in Ukraine currently provides assistance to internally displaced persons and people affected by the conflict, combats trafficking in human beings, assists the government in combating unregulated migration and improving the management of migration processes, and develops a health policy tailored to migrants [10]. Currently, the basis of migration legislation of Ukraine is the Law of Ukraine "On External Labor Migration" [11] and "Strategy of State Migration Policy of Ukraine until 2025" [12].

In early 2020, labor migration processes were slowed down, and for some migrants suspended due to the COVID-19 pandemic. The new pandemic has caused a number of problems in the socio-economic spheres of all countries. At such an extremely difficult time for the whole world, Ukrainian migrants abroad are in dire need of support and protection from the Ukrainian government. After all, migrants are the backbone of the Ukrainian economy: remittances to Ukraine account for more than 10\% of GDP. The families of labor migrants in Ukraine use the money sent to meet their basic needs, including food, rent, education and medicine. As a result, COVID-19 and associated travel restrictions threaten households whose main source of income is remittances. A decline in remittances can have significant spillover effects on local economies and communities as a whole, resulting in reduced productive investment, consumer spending, and access to education and health services. Since movement restrictions are still in place, governments are considering accepting migrants, making exceptions for them in order to eliminate the deficit that has arisen in the regions depends on seasonal work.

As one of the main countries of origin for labor migrants, Ukraine is being approached by foreign governments to facilitate the movement of seasonal workers and thus meet the needs of their labor markets. The Ukrainian government is taking a cautious approach to balance the 
needs of its citizens seeking work abroad with the related public health aspects of global displacement.

To achieve the primary goal of protecting Ukrainian citizens, the following measures must be taken:

- $\quad$ support the development and operation of the national framework for circular migration, in particular bilateral and multilateral cooperation with destination countries;

- medical examinations before departure and medical certification of labor migrants;

- informing migrants before departure and cultural orientation, which facilitates and accelerates adaptation in the country of destination;

- $\quad$ support upon arrival in the destination country;

- $\quad$ providing support for return and after return, as well as support for reintegration in Ukraine [13].

However, the issue of protection of Ukrainian migrants abroad arose long before the beginning of the COVID-19 pandemic. The most common problem faced by a migrant worker is exploitation. Dishonest employers violate the labor laws of their countries by forcing foreign workers to work overtime for insufficient pay and exceeding working time limits, do not pay wages on time or in sufficient amounts, do not provide workers with the necessary living and working conditions. This is not a complete list of violations committed by foreign employers, as some of them are even involved in human trafficking.

The exploitation of Ukrainian citizens abroad is becoming more widespread. According to the International Organization for Migration (IOM) from 2014 to 2019, 6573 victims of human trafficking were identified (Figure 1).

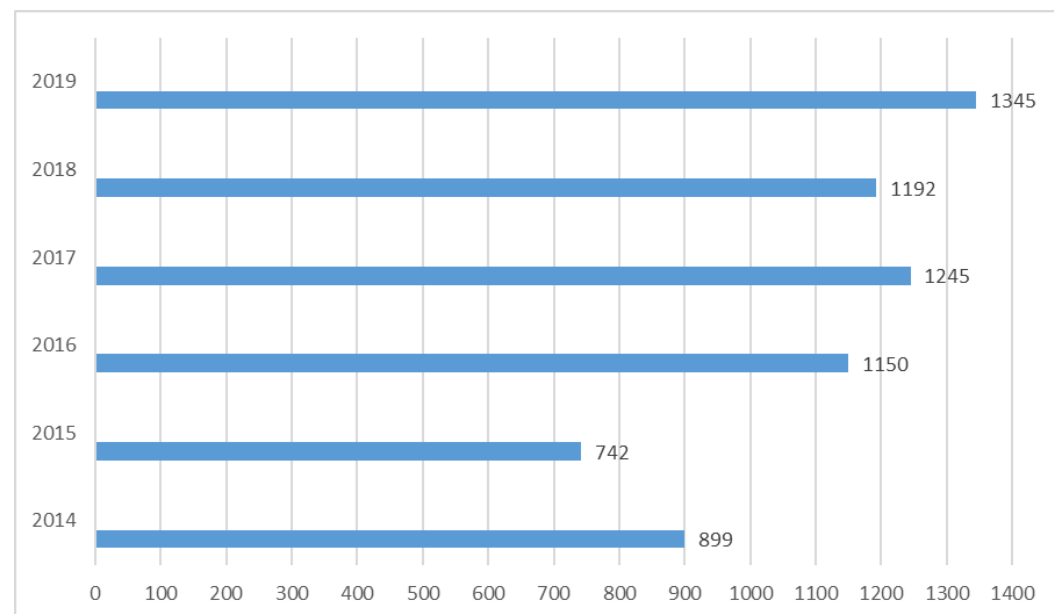

Figure 1 - Number of identified victims (2014-2019) [14]

The main reasons for the spread of labor exploitation among Ukrainian labor migrants are the low level of awareness of this phenomenon and their rights, as well as the neglect of their own safety. In view of the above, outreach work among the population should be aimed at emphasizing the need to:

- job search through official channels;

- concluding a formal written contract with the employer;

- obtaining official documents that allow you to work in another country (work visa, permit or invitation from the employer);

- $\quad$ agreement in the contract on the type and place of work, the number of working hours and the availability of social benefits (paid sick leave, weekends, holidays).

Thus, it is necessary to draw conclusions about the feasibility of reforming and improving the system of informing the public about the possible threats that workers may face 
when traveling abroad. It should be remembered that official statistics show only the registered facts of offenses by employers, so the state must always be ready to protect its citizens, regardless of which country they went to.

\section{CONCLUSIONS}

International migration is one of the most characteristic manifestations of globalization of the world economy. The development of information and communication technologies, reducing the cost of transport, capital movements, transnationalization of production lead to stronger relations and interdependence between countries, and hence to increased labor mobility. The multifactorial impact of migration on the socio-economic situation of countries requires constant monitoring of the number and structure of migrant workers. In this context, it is important to improve the system of regulation of personnel migration in order to benefit from the state's participation in migration processes. Which is extremely important during the COVID-19 pandemic, which had a negative impact on the economy as a whole, but also on the well-being of each individual family.

Assessment and forecasting of external migration allow us to decide on the need for means of regulating migration flows. The influence of the state on migration processes takes the form of regulating the quantitative and qualitative composition of migrants, protecting their rights and freedoms and can be carried out directly or indirectly.

To improve the system of state regulation of international migration in Ukraine, it is proposed to improve the legal framework for regulating the migration of personnel in matters of recognition of work experience of migrants received abroad, pensions, the activities of international employment agencies. It is necessary to create a single information system that will collect statistical information on the scale and structure of migration flows to and from Ukraine. In order to minimize shadow migration from Ukraine, it is necessary to develop a single information system on the conditions and rules of employment abroad. Stimulation of reemigration will be facilitated by the mechanism of preferential lending to re-emigrants for housing purchase, increase in the number of jobs in Ukraine, increase in wages, overcoming the military-political crisis. It is desirable to simplify the mechanism of private transfers of funds from abroad.

\section{АНОТАЦІЯ}

В умовах глобалізації всі економіки світу об'єднуються, взаємодіють і розвиваються в єдиній системі виробництва. Однак світова економіка значною мірою залежить від формування та розвитку світового ринку праці. Таким чином, міграція є одним із основних механізмів та факторів, що впливають на окремі країни та світову економіку в цілому.

3 посиленням процесів глобалізації попит на персонал різного рівня кваліфікації на ринку праці задовольняється пропозицією працівників незалежно від країни, в якій вони проживають. Це явище призводить до міжнародної трудової міграції. Незважаючи на те, що міграція висококваліфікованого персоналу призводить до інтелектуального занепаду та відсутності освіченого населення в країні, з якої мігрують працівники. Натомість неконтрольована міграція низько кваліфікованого персоналу в країні перебування може призвести до різкого зростання безробіття серед місцевого населення, кримінальних правопорушень, соціального невдоволення громадян, що негативно позначиться на авторитеті держави у світі. Тому вивчення системи регулювання міграційних процесів та впровадження шляхів ії вдосконалення допоможуть гармонізувати соціально-економічну ситуацію у світі та зробити міграцію більш прибутковою та безпечною для країн та ії громадян.

У статті відображено основні сучасні тенденції міжнародних міграційних процесів: напрями зовнішньої трудової міграції, масштаби виїзду трудових мігрантів до різних країн, визначено причини таких тенденцій. У ході дослідження розглядаються методи, за допомогою яких ці процеси регулюються для покращення економіки країн та безпеки трудових мігрантів.

У дослідженні також описується вплив пандемії COVID-19 на мобільність громадян України та методи подолання наслідків цього впливу. Дії, описані у статті, пов'язані з міграцією та мобільністю населення, пом'якшать довгострокові наслідки пандемії, допоможуть посилити захист громадян України за кордоном, а також розширять можливості їх соціально-економічної інтеграції у місцеві громади.

Ключові слова: глобалізація, міграційні процеси, міжнародна міграція робочої сили, державне регулювання міграції.

\section{СПИСОК ЛІТЕРАТУРИ}

1. Новий словник іншомовних слів: близько 40000 слів. / за ред. Л.І. Шевченко. - К.: АРІЙ, 2008 - 384 c. 
2. Міграційні явища та процеси: поняття, методи, факти: довідник. / В.С. Кравців, У.Я. Садова та ін. Львів: Інститут регіональних досліджень НАН України, 2009. - 66 с.

3. Лібанова Е. М. Зовнішні трудові міграції українців: масштаби, причини, наслідки. Демографія та соціальна економіка. 2018. № 2(33). С. 11-26.

4. Економічна енциклопедія: У трьох томах. - Том 2 / Редкол.: С.В. Мочерний (відп. ред.) та ін. - Київ: Видавничий центр «Академія», 2001. - 848 с.

5. Сучасні тенденції міжнародної міграції трудових ресурсів. URL: http://bses.in.ua/journals/2016/121_2016/10.pdf.

6. Миграция. Интерактивные приложения // Федеральная служба государственной статистики. URL: http://www.gks.ru/wps/wcm/connect/rosstat_main/rosstat/ru/apps/6ec1b4004a47e110a974abf75a2eeced.

7. Asylum and managed migration // Eurostat, 2019. URL: http://ec.europa.eu/eurostat/web/asylum-and-managed-migration/data/database.

8. Нагорнова О.В.Державне регулювання трудової міграції в умовах ринкової трансформації економіки України: автореф. дис. на здобуття наук. ступеня канд. екон. наук : спец. 08.00.03 «Економіка та управління національним господарством». Львів, 2008. - 21 с.

9. Сірант М. Вплив глобалізаційних процесів на формування потоків трудової міграції // Вісник Національного університету «Львівська політехніка». Юридичні науки, 2014. № 782. С. 38 -43.

10. Міжнародна організація 3 міграції: MOM в http://iom.org.ua/ua/mom-v-ukrayini

11. Про зовнішню трудову міграцію: Закон України від 05.11.2015 № 761-19/Відомості Верховної Ради (BBP), 2015. № 49-50. ст. 463. URL: http://zakon5.rada.gov.ua/laws/show/761-19

12. Про схвалення Стратегї̈ державної міграційної політики України на період до 2025 року / Кабінет Міністрів України; Розпорядження 12 липня 2017 p. № 482-p. URL: http://zakon5.rada.gov.ua/laws/show/482-2017-\%D1\%80

13. Подолання наслідків впливу COVID-19 на мобільність населення. URL https://iom.org.ua/sites/default/files/iom ukraine covid-19 migration messages ukr.pdf

14. Про затвердження плану заходів на 2018-2021 роки щодо реалізації Стратегії державної міграційної політики України на період до 2025 року: Розпорядження Кабінету Міністрів України від 29 серпня 2018 р. № 602-p. / Верховна Рада України. URL: https://zakon.rada.gov.ua/laws/show/602-2018

\section{REFERENCES}

1. New dictionary of foreign words: about 40,000 words. / for ed. L.I. Shevchenko. - K .: ARIY, 2008. 384 c.

2. Migration phenomena and processes: concepts, methods, facts: handbook. / V.S. Kravtsiv, U.Ya. Sadova and others. - Lviv: Institute for Regional Studies of the National Academy of Sciences of Ukraine, 2009. - 66 p.

3. Libanova E.M. External labor migration of Ukrainians: scale, causes, consequences. Demography and social economy. 2018. № 2 (33). Pp. 11-26.

4. Economic Encyclopedia: In three volumes. - Volume 2 / Editor: S.V. Mocherny (responsible editor) and others. - Kyiv: Publishing Center "Academy", 2001. - 848 p.

5. Modern tendencies of international labor migration. URL: http://bses.in.ua/journals/2016/12-1_2016/10.pdf Migration.

6. Interactive applications // Federal State Statistics Service. URL: http: //www.gks.ru/wps/wcm/connect/rosstat_main/rosstat/ru/apps/6ec1b4004a47e110a974abf75a2eeced.

7. Asylum and managed migration // Eurostat, 2019. URL: http://ec.europa.eu/eurostat/web/asylum-andmanaged-migration/data/database.

8. Nagornova O.V. State regulation of labor migration in the conditions of market transformation of the economy of Ukraine: author's ref. dis. for science. degree of Cand. econ. Science: special. 08.00.03 "Economics and management of the national economy". Lviv, 2008. - 21 p.

9. Sirant M. Influence of globalization processes on the formation of labor migration flows // Bulletin of the National University "Lviv Polytechnic". Juridical sciences, 2014. № 782. S. 38-43.

10. International Organization for Migration: IOM in Ukraine. URL: http://iom.org.ua/ua/mom-v-ukrayini.

11. On external labor migration: Law of Ukraine of 05.11.2015 № 761-19 / Bulletin of the Verkhovna Rada (VVR), 2015. № 49-50. Art. 463. URL: http://zakon5.rada.gov.ua/laws/show/761-19.

12. On approval of the Strategy of the state migration policy of Ukraine for the period up to 2025 / Cabinet of Ministers of Ukraine; Order of July 12, 2017. № 482-r. URL: http://zakon5.rada.gov.ua/laws/show/4822017-\%D1\%80.

13. Overcoming the effects of COVID-19 on population mobility. URL https://iom.org.ua/sites/default/files/iom_ukraine_covid-19_migration_messages_ukr.pdf.

14. On approval of the action plan for 2018-2021 for the implementation of the Strategy of the state migration policy of Ukraine for the period up to 2025: Order of the Cabinet of Ministers of Ukraine of August 29, 2018. № 602-r. / Verkhovna Rada of Ukraine. URL: https://zakon.rada.gov.ua/laws/show/602-2018. 